\title{
Hubungan Nilai Rapor Biologi dengan Kompetensi Biologi Umum I Mahasiswa FMIPA Semester I T.P 2015/2016 Berdasarkan Jalur Masuk di Universitas Negeri Medan
}

\author{
Mery Tiurma Sinaga ${ }^{1}$, Binari Manurung ${ }^{2}$, Tumiur Gultom ${ }^{2}$ \\ ${ }^{1}$ Guru Biologi di SMP Negeri 2 Bosarmaligas \\ ${ }^{2}$ Program Studi Pendidikan Biologi Pascasarjana Universitas Negeri Medan, Sumatera Utara, Indonesia \\ E-mail: merynaga@gmail.com
}

\begin{abstract}
This research aims are to determaine the relationship between raport value (X) and competence general biology I (Y) student college FMIPA level I T.P 2015/2016 based on the path to State University of Medan (SNMPTN, Bidikmisi, SBMPTN, UMB). This research is study using descriptive correlational. Population in this research were all the student FMIPA Level I of State University of Medan T.P 2015/2016 which amounted 1159 people. Sample was taken by Proportional Stratified Sampling obtained 176 people. Analysis techniques data is using multiple corellation. The study concluded that there was a relationship between raport value $(\mathrm{X})$ and competence general biology I (Y), based on SBMPTN are 0.333 the regression equation $\hat{Y}=68.122+5.481 \mathrm{X}_{1}$, SNMPTN are 0.117 the regression equation $\hat{Y}=18.093+0.363 \mathrm{X}_{1}$, Bidikmisi are 0.188 the regression equation $\hat{Y}=1.662+0.017 \mathrm{X}_{1}$ and $\mathrm{UMB}$ are -0.015 the regression equation $\hat{\mathrm{Y}}=3.161+\left(-0.001 \mathrm{X}_{1}\right)$.
\end{abstract}

Key Word: Raport value, General Biology Value, Path away to University

\section{PENDAHULUAN}

Evaluasi sebagai salah satu alat ukur dalam penilaian hasil belajar. Berbagai tipe penilaian dilaksanakan pada waktu yang berbeda dan untuk tujuan yang berbeda pula. Dengan demikian, evaluasi merupakan suatu istilah yang dipahami dengan banyak makna. Menurut Brink dalam Akmal (2006) menyatakan bahwa evaluasi tidak hanya berkenaan dengan pengujian dan pengambilan nilai, melainkan lebih dari itu, evaluasi merupakan proses penjaringan informasi yang dibutuhkan untuk digunakan sebagai bahan pertimbangan pengambilan keputusan dalam hal proses belajar mengajar secara umum.

Pelaksanaan evaluasi dalam pembelajaran, bagi guru maupun bagi siswa tidak hanya sebatas mendistribusikan soal dan mendapatkan nilai. Guru yang baik akan senantiasa mencari cara terbaik untuk dapat menyajikan materi dengan cara yang efektif bagi siswanya. Sebab itu, seorang guru akan membutuhkan informasi mengenai para siswanya, terutama mengenai kemampuan pencapaian, ketertarikan, kelebihan dan kekurangan, serta permasalahan siswa tersebut.
Hasil evaluasi memberikan informasi tentang sejauh mana siswa telah menguasai bahan pelajaran yang disajikan guru. Dengan informasi ini siswa dapat mengambil langkah-langkah yang sesuai (Suke, 1991). Semua orang tua ingin melihat sejauh mana tingkat kemajuan yang dicapai anaknya di sekolah, kendatipun pengetahuan itu tidak menjamin adanya upaya dari mereka untuk peningkatan kemajuan anaknya.

Oleh karena itu setiap caturwulan atau semester, sekolah memberikan laporan kemajuan siswa kepada orang tuanya dalam bentuk buku rapor. Dalam buku rapor itu tidak lain dari hasil evaluasi yang dibuat oleh guru dan semua petugas sekolah terhadap siswa (Suke, 1991). Buku rapor berisi hasil evaluasi yang dibuat guru dan hasil semua tugas sekolah peserta didik.

Buku Rapor adalah suatu cara pengukuran kinerja siswa. Umumnya laporan ini diberikan oleh sekolah kepada siswa atau orang tua siswa dua kali hingga empat kali dalam setahun (Wikipedia, 2016). Sistem buku rapor biasanya menggunakan skala pemeringkatan untuk menentukan kualitas hasil kerja murid di sekolah. Sistem skala ini dapat berupa huruf (misalnya A, B, C, D, E, dan F). Dengan A 
adalah kinerja tertinggi dan $\mathrm{F}$ bererti gagal atau angka (misalnya $\mathrm{A}=90, \mathrm{~B}-80-89$, $\mathrm{C}=70-79, \mathrm{D}=60-69, \mathrm{E}=50-59$ dan $\mathrm{F}=0-49$ ). $\mathrm{Di}$ Indonesia saat ini rapor diisi menggunakan skala nilai angka dengan rentang 0 sampai dengan 100 .

Rapor merupakan dokumen yang menjadi penhubung komunikasi baik antara sekolah dengan orangtua peserta didik maupun dengan pihak-pihak lain yang ingin mengetahui tentang hasil belajar anak pada kurun waktu tertentu. Karena itu, rapor harus komunikatif, informatif, dan komprehensif (menyeluruh) memberikan gambaran tentang hasil belajar peserta didik.

Kurikulum Tingkat Satuan Pendidikan dikembangkan sesuai dengan karakteristik masing-masing mata pelajaran. Setiap mata pelajaran memiliki dimensi yang berbeda satu dengan lainnya, sehingga orientasi pembelajaran dan penilaian adalah penugasan kompetensi sesuai dengan dimensi masing-masing mata pelajaran. Dengan demikian nilai pada rapor bukan nilai tunggal tetapi dikelompokkan menurut dimensi masing-masing mata pelajaran.

Kebijakan Kemendiknas yang mengubah cara penerimaan mahasiswa baru dari cara konvensional (melalui seleksi test) ke seleksi nilai rapor telah dimulai tahun 2013. Kuota mahasiswa baru setiap PTN tidak $100 \%$ melalui jalur seleksi nilai rapor yang dikenal istilahnya dengan SNMPTN, tetapi ada $50 \%$ dari kuota yang ada kembali melakukan seleksi melalui jalur tes tertulis yang dikenal dengan istilah SBMPTN (Supratno, 2009).

Pada penerimaan mahasiswa baru melalui jalur Seleksi Nasional Masuk Perguruan Tinggi Negeri (SNMPTN), rapor merupakan salah satu faktor penting untuk kelulusan yang seluruh pesertanya merupakan pelajar akhir di kelas XII atau kelas 3 SMA sederajat. Penerimaan mahasiswa baru harus memenuhi prinsip adil, akuntabel, tarnsparan, dan tidak deskriminatif dengan tidak membedakan jenis kelamin, agama, suku, ras, kedudukan sosial, dan tingkat kemampuan ekonomi calon mahasiswa serta tetap memperhatikan potensi calon mahasiswa dan kekhususan perguruan tinggi.

Seleksi Nasional Masuk Perguruan Tinggi Negeri (SNMPTN) adalah salah satu bentuk jalur seleksi penerimaan mahasiswa untuk memasuki perguruan tinggi negeri yang dilaksanakan serentak di seluruh Indonesia, selain seleksi mandiri (melalui Ujian Mandiri) serta Seleksi Bersama Masuk Perguruan Tinggi Negeri (SBMPTN).

SNMPTN undangan yang menggunakan jalur prestasi akademik yaitu dengan menggunakan nilai rapor selama 5 semester. Maka terdapat nilai positif dan negatif yang ditimbulkan dari adanya SNMPTN undangan. Nilai positifnya yaitu adanya semangat bagi siswa untuk terus berprestasi dan meningkatkan nilai rapor mereka agar dapat lolos verifikasi data untuk SNMPTN undangan, dimana mereka tidak harus melewati ujian tulis.

Seperti halnya mata pisau yang memiliki sisi positif dan negatif. Sisi negatif dari SNMPTN undangan yaitu adanya kemungkinan kecurangan baik dari pihak siswa maupun pihak sekolah untuk berusaha memberikan nilai yang baik untuk rapor siswa. Dengan adanya SNMPTN undangan ini, ditakutkan adanya peningkatan kecurangan siswa dalam mengerjakan ujian maupun adanya dari pihak sekolah yang memanipulasi nilai siswa (Nurlina, 2012).

Mahasiswa yang lolos melalui salah satu jalur penerimaan masuk PTN dibagi menjadi beberapa kelas yang berbeda sesuai dengan jalur yang telah mereka tempuh. Mahasiswa dikatakan berhasil atau tidak, salah satunya dengan melihat nilai-nilai perolehan mahasiswa dalam Kartu Hasil Studi (KHS). Angka-angka maupun hurufhuruf dalam KHS mencerminkan indeks prestasi belajar atau sejauh mana tingkat keberhasilan siswa mengikuti kegiatan belajar.

Penilaian hasil belajar mahasiswa biasanya dinyatakan dalam bentuk huruf yaitu $\mathrm{A}, \mathrm{B}, \mathrm{C}, \mathrm{D}$ dan $\mathrm{E}$ yang masingmasing bernilai 4, 3, 2, 1, dan 0 (Sudiyono, 2004). Huruf A-E disebut dengan huruf mutu yang apabila dikonversikan pada 
angka mutu dan sebutan mutu dapat dinyatakan sebagai berikut:

Tabel 1. Huruf Mutu dan Angka Mutu Mata Kuliah Semester I

\begin{tabular}{cccl}
\hline Nilai & $\begin{array}{c}\text { Huruf } \\
\text { Mutu } \\
\text { (HM) }\end{array}$ & $\begin{array}{c}\text { Angka } \\
\text { Mutu } \\
\text { (AM) }\end{array}$ & $\begin{array}{c}\text { Sebutan Mutu } \\
\text { (Predicate) }\end{array}$ \\
\hline $90-100$ & A & 4 & Baik Sekali \\
$80-89$ & B & 3 & Baik Sekali \\
$70-79$ & C & 2 & Cukup \\
$60-69$ & D & 1 & Tidak Lulus \\
$00-59$ & E & 0 & Tidak Lulus \\
& TL & - & Tidak Lengkap \\
\hline
\end{tabular}

(Sumber: Dokumen LHS UNIMED)

Tidak Lengkap merupakan indikator ketidaklengkapan seseorang mahasiswa dalam memenuhi seluruh persyarakatan untuk memperoleh penilaian keberhasilan proses belajar mahasiswa pada suatu mata kuliah seperti yang telah ditentukan dalam rencana perkuliahan (Burhanuddin, 2005).

Biologi Umum adalah salah satu Mata Kuliah Umum yang wajib dikuasai oleh mahasiswa FMIPA pada Universitas Negeri Medan. Mata Kuliah Biologi Umum wajib dikuasai pada Semester I dan II. Setiap akhir semester maka seluruh mahasiswa FMIPA wajib mengikuti Ujian Kompetensi Biologi. Nilai yang dihasilkan adalah nilai murni hasil perolehan mahasiswa yang dikerjakan pada Lembar Kerja Komputer.

Untuk itu peneliti ingin melakukan penelitian seberapa kuat "Hubungan antara rata-rata nilai rapor Biologi mahasiswa saat masih di bangku SMA dengan nilai Kompetensi Biologi Umum mahasiswa saat berada di universitas".

\section{METODE PENELITIAN}

Jenis penelitian ini adalah penelitian deskriptif studi korelasi. Penelitian ini dilaksanakan di Fakultas Matematika dan Ilmu Pengetahuan Alam (FMIPA) Universitas Negeri Medan semester ganjil T.A 2015/2016. Populasi dalam penelitian ini adalah mahasiswa FMIPA semester I yang berjumlah 1159 orang dan sampel diambil secara Proportional Stratified Sampling sehingga berjumlah 176 orang (Sumber: Tata Usaha FMIPA UNIMED, 2016).
Teknik pengumpulan data dalam penelitian ini dilakukan dengan dokumentasi berupa data sekunder yang telah diarsipkan di kantor FMIPA UNIMED berupa rata-rata nilai rapor Biologi dan nilai Biologi Umum I yang merupakan hasil ujian bersama. Data dalam penelitian ini dianalisis dengan menggunakan korelasi Regresi Ganda.

\section{HASIL DAN PEMBAHASAN}

Rata-rata nilai Ujian Nasional Biologi dan rata-rata nilai Biologi Umum I berdasarkan jalur masuk Seleksi Nasional Masuk Perguruan Tinggi (SNMPTN), Bidikmisi, Seleksi Bersama Masuk Perguruan Tinggi Negeri (SBMPTN) dan Ujian Masuk Bersama (UMB) dapat diamati pada Tabel 1. dibawah ini:

Tabel 1. Rata-rata Nilai UN Biologi dan Nilai Biologi Umum I mahasiswa melalui jalur SNMPTN, Bidikmisi, SBMPTN dan UMB

\begin{tabular}{lccc}
\hline \multirow{2}{*}{ Jalur } & \multirow{2}{*}{$\mathbf{N}$} & \multicolumn{2}{c}{ Nilai Rata-rata $(\mathbf{X})$} \\
\cline { 3 - 4 } & & $\begin{array}{c}\text { N. Rapor } \\
\text { Biologi }\end{array}$ & $\begin{array}{c}\text { N. Biologi } \\
\text { Umum I }\end{array}$ \\
\hline SNMPTN & 56 & 87,82 & 49,96 \\
\hline Bidikmisi & 34 & $\mathbf{9 1 , 0 5}$ & 50,88 \\
\hline SBMPTN & 45 & 85,91 & $\mathbf{5 3 , 3 3}$ \\
\hline UMB & 41 & 85,27 & 50,54 \\
\hline
\end{tabular}

Pada Tabel 1 dikemukakan bahwa ratarata nilai rapor Biologi tertinggi diperoleh oleh mahasiswa FMIPA yang masuk melalui jalur Bidikmisi sedangkan untuk nilai biologi umum I tertinggi dimiliki oleh mahasiswa FMIPA yang masuk melalui jalur SBMPTN.

\section{Pengujian Hipotesis}

Untuk menguji apakah ada hubungan dan seberapa besar kontribusi antara variabel digunakan Uji Regresi Ganda. Hasil dari pengujian Hipotesis dapat kita amati pada Tabel 2 berikut ini:

Tabel 2. Pengujian Hipotesis jalur SNMPTN

\begin{tabular}{rrrrr} 
Model & $\mathrm{R}$ & $\begin{array}{c}\mathrm{R} \\
\text { Square }\end{array}$ & $\begin{array}{r}\text { Adjusted } \\
\text { R Square }\end{array}$ & \multicolumn{1}{c}{$\begin{array}{l}\text { Durbin- } \\
\text { Watson }\end{array}$} \\
\hline 1 &, $117 \mathrm{a}$ &, 014 &,- 004 & 1,584 \\
\hline
\end{tabular}

a. Predictor: (constant), Rapor 
b. Dependent Variable: Nilai Biologi Umum I Tabel 3. Pengujian Hipotesis jalur Bidikmisi

\begin{tabular}{crrrr}
\hline Model & R & $\begin{array}{c}\text { R } \\
\text { Square }\end{array}$ & $\begin{array}{r}\text { Adjusted } \\
\text { R Square }\end{array}$ & $\begin{array}{r}\text { Durbin- } \\
\text { Watson }\end{array}$ \\
\hline 1 &, $045 \mathrm{a}$ &, 002 &,- 029 & 1,943 \\
\hline
\end{tabular}

a. Predictor: (constant), Rapor

b. Dependent Variable: Nilai Biologi Umum I

Tabel 4. Pengujian Hipotesis jalur SBMPTN

\begin{tabular}{ccccc}
\hline Model & $\mathrm{R}$ & $\begin{array}{c}\mathrm{R} \\
\text { Square }\end{array}$ & $\begin{array}{c}\text { Adjusted } \\
\text { R Square }\end{array}$ & $\begin{array}{c}\text { Durbin- } \\
\text { Watson }\end{array}$ \\
\hline $1 \quad, 002 \mathrm{a}$ &, 000 &,- 023 & 1,577 \\
\hline \multicolumn{3}{l}{ a. Predictor: (constant), Rapor } \\
b. Dependent Variable: NilaiBioUmI
\end{tabular}

Tabel 5. Pengujian Hipotesis jalur UMB

\begin{tabular}{ccrrr}
\hline Model & $\mathrm{R}$ & $\begin{array}{c}\mathrm{R} \\
\text { Square }\end{array}$ & $\begin{array}{c}\text { Adjusted } \\
\text { R Square }\end{array}$ & $\begin{array}{c}\text { Durbin- } \\
\text { Watson }\end{array}$ \\
\hline $1 \quad, 069 \mathrm{a}$ &, 005 &,- 021 & 1,938 \\
\hline \multicolumn{3}{l}{ a. Predictor: (constant), Rapor } \\
b. Dependent Variable: NilaiBioUmI
\end{tabular}

Tabel 2 menunjukkan bahwa hubungan antara nilai rata-rata rapor Biologi $\left(\mathrm{X}_{1}\right)$ dengan nilai Biologi Umum I $\left(\mathrm{Y}_{1}\right)$ dalam bentuk persamaan regresi linear sederhana dapat dituliskan sebabagi berikut: $\hat{Y}=$ $18,093+0,363 \mathrm{X}_{1}$.

Nilai korelasinya 0,117 ini korelasi yang sangat rendah. Nilai determinan 0,014 atau $(1,4 \%)$ berarti persentase sumbangan nilai rapor Biologi $\left(\mathrm{X}_{1}\right)$ terhadap variabel nilai Biologi Umum (Y1) sebesar 1,4\%. Sedangkan sisanya sebesar $98,4 \%$ ditentukan oleh variabel lain.

Tabel 3 menunjukkan bahwa Hubungan antara nilai rata-rata rapor Biologi $\left(\mathrm{X}_{1}\right)$ dengan nilai Biologi Umum I $\left(\mathrm{Y}_{1}\right)$ dalam bentuk persamaan regresi linear sederhanan dapat dituliskan sebabagi berikut: $\hat{Y}=90,338+0,014 X_{1}$.

Nilai korelasinya 0,045 ini korelasi yang sangat rendah. Nilai determinan 0,020 atau $(2,0 \%)$ berarti persentase sumbangan nilai rapor Biologi $\left(\mathrm{X}_{1}\right)$ terhadap variabel nilai biologi umum (Y1) sebesar 2,0\%. Sedangkan sisanya sebesar $98,0 \%$ ditentukan oleh variabel lain.

Tabel 4 menunjukkan bahwa Hubungan antara nilai rata-rata rapor
Biologi $\left(\mathrm{X}_{1}\right)$ dengan nilai Biologi Umum I $\left(\mathrm{Y}_{1}\right)$ dalam bentuk persamaan regresi linear sederhanan dapat dituliskan sebabagi berikut: $\hat{\mathrm{Y}}=53,010+0,004 \mathrm{X}_{1}$.

Nilai korelasinya 0,002 ini korelasi yang sangat rendah. Nilai determinan 0,000 atau $(0 \%)$ berarti persentase sumbangan nilai rapor Biologi $\left(\mathrm{X}_{1}\right)$ terhadap variabel nilai Biologi Umum (Y1) sebesar 0\%.

Tabel 5 menunjukkan bahwa Hubungan antara nilai rata-rata rapor Biologi $\left(\mathrm{X}_{1}\right)$ dengan nilai Biologi Umum I $\left(\mathrm{Y}_{1}\right)$ dalam bentuk persamaan regresi linear sederhanan dapat dituliskan sebabagi berikut: $\hat{Y}=37,918+0,148 X_{1}$.

Nilai korelasinya 0,069 ini korelasi yang sangat rendah dengan nilai determinan 0,05 atau $(5 \%)$ berarti persentase sumbangan nilai rapor Biologi $\left(\mathrm{X}_{1}\right)$ terhadap variabel nilai Biologi Umum (Y1) sebesar 5\%. Sedangkan $95 \%$ lagi dipengaruhi oleh faktor lain.

\section{PEMBAHASAN}

Dari perhitungan antara variabel nilai rata-rata rapor Biologi $\left(\mathrm{X}_{1}\right)$ dengan nilai Biologi Umum I $\left(\mathrm{Y}_{1}\right)$ berdasarkan jalur masuk SNMPTN, Bidikmisi, SBMPTN dan UMB diperoleh bahwa nilai hubungan yang antara nilai rata-rata rapor Biologi $\left(\mathrm{X}_{1}\right)$ dengan nilai Biologi Umum I $\left(\mathrm{Y}_{1}\right)$ sangat tidak erat dan tidak mempunyai hubungan yang signifikan antara nilai rata-rata rapor Biologi dengan nilai Biologi Umum I.

Seharusnya jika mahasiswa saat masih di bangku SMA memiliki nilai rata-rata rapor Biologi yang erat maka siswa tersebut tidak akan mengalami kesulitan untuk memperoleh nilai Biologi Umum saat di bangku kuliah. Namun hal ini tidak sejalan dengan hasil penelitian ini, semua jalur masuk (SNMPTN, Bidikmisi, SBMPTN dan UMB) memiliki korelasi yang sangat rendah antara nilai rata-rata rapor Biologi $\left(\mathrm{X}_{1}\right)$ dengan nilai Biologi Umum I $\left(\mathrm{Y}_{1}\right)$. Hal ini mungkin disebabkan oleh faktor lain seperti contohnya faktor sosial. Hal ini sejalan dengan penelitian Daruyani (2013) menyatakan bahwa prestasi belajar mahasiswa semester I dipengaruhi oleh hubungan mahasiswa dengan teman (sosial). Hal ini juga dimungkinkan karena 
perolehan nilai rapor biologi saat mahasiswa berada pada jenjang SMA, belum dapat digunakan sebagai syarat dalam memasuki jenjang berikutnya.

Dari pengolahan data diperoleh bahwa hubungan yang kurang erat antara nilai rapor dan UN saat sekolah menengah dengan nilai biologi dan indeks prestasi saat di bangku kuliah. Dapat disimpulkan pemanfaatan nilai ujian nasional (UN) dan nilai rapor digunakan untuk tahapan menuju ke jenjang yang lebih lanjut masih kurang efektif. Terutama nilai rapor, karena dari semua jalur masuk tidak terdapat hubungan yang signifikan terhadap variabel nilai Biologi Umum I. Perlu perbaikan ke arah yang lebih baik sehingga diperoleh nilai lulusan sesuai dengan kemampuan setiap peserta didik.

Dari hasil penelitian ini dapat dilihat bahwa jikalau seleksi masuk perguruan tinggi melalui jalur SBMPTN (ujian tulis) dihapus dan hanya menggunakan jalur SNMPTN (jalur undangan) maka sistem ini dinilai berpotensi munculnya upaya manipulasi nilai rapor yang masih aktif di sekolah. Meskipun hal itu telah coba diantisipasi dengan membuat Pangkalan Data Sekolah dan Siswa (PDSS) sehingga basis data berisikan rekam jejak dan prestasi akademik siswa yang minat masuk jalur undangan (Rosana, 2014). Aminudis mengatakan dalam sosialisasi SNMPTN bahwa proses pengisian PDSS harus objektif dan benar, apabila sekolah memanipulasi data maka akan masuk daftar hitam (black list) dalam SNMPTN tahun berikutnya.

Dengan kata lain, jika hasil penelitian ini diamati kebijakan menghapus jalur tulis dan hanya menggunakan jalur undangan untuk masuk Perguruan Tinggi Negeri (PTN) dianggap masih kurang tepat selama belum ada perbaikan dalam menghasilkan lulusan yang kompeten.

\section{SIMPULAN}

Simpulan yang dapat ditarik dari hasil pengujian hipotesis adalah hubungan antara nilai UN dengan Biologi Umum I tertinggi diperoleh oleh mahasiswa yang masuk melalui jalur SBMPTN dengan nilai korelasi 0,002 (korelasi sangat rendah), nilai determinan 0,000 atau (0\%). Pada jalur SNMPTN nilai korelasinya 0,117 (korelasi yang sangat rendah) dengan nilai determinan 0,014 atau $(1,4 \%)$. Pada jalur Bidikmisi, nilai korelasinya 0,045 (korelasi yang sangat rendah) dengan nilai determinan 0,020 atau $(2,0 \%)$ dan pada jalur UMB nilai korelasinya 0,069 (korelasi yang sangat rendah) dengan nilai determinan 0,05 atau (5\%).

\section{DAFTAR PUSTAKA}

Aminuddin. 2015. Memanipulasi Data PSDS, Sekolah Bisa Masuk Daftar Hitam. Portal Berita UPI. Online (http://berita.upi.edu/? $\mathrm{p}=2588$ ).

Akmal. 2006. Analisis Kualitas Naskah Ujian Akhir Semester Mata Kuliah Bahasa Inggris II Politehnik Negeri Lampung tahun 2006. Jurnal Ilmiah Esai, Vol.2(1).

Burhanuddin. 2005. Administrasi Pendidikan. Bandung: Pustaka Setia.

Daruyani. 2013. Faktor-Faktor Yang Mempengaruhi Indeks Prestasi Mahasiswa FSM Universitas Dipenogoro Semester I. Jurnal Gaussia, 2(4): 385-394.

Nurlina. 2012. Mengoreksi Kembali Keberadaan SNMPTN Undangan. LPM Visi. Artikel Online.

Rosana, D dan Sukardiyono. 2014. Model Assessment Terstandar Berbasis Computer Management Instructional untuk Menjamin Kesetaraan Kualitas Penilaian Sebagai Basis Data Penetuan Kelulusan Dalam Sistem Ujian Akhir nasional dan SNMPTN Jalur Undangan yang Berkeadilan. Artikel Peneltian Hibah Kompetensi.

Sudiyono. 2004, Manajemen Pendidikan Tinggi, Jakarta: Rineka Cipta

Suke, S. 1991. Evaluasi Hasil Belajar dan Umpan Balik. Jakarta. Grasindo.

Supratno. 2009. Buku Panduan Peserta SNMPTN 2009 Wilayah I. Panitia Pelaksanaan SNMPTN 2009. Jakarta. 